\title{
Pemanfaatan Multimedia Sebagai Media Promosi Destinasi Wisata Dan Produk Oleh-Oleh Desa Wisata Di Desa Kebontunggul Kecamatan Gondang Kabupaten Mojokerto
}

\author{
Widhayani Puri Setioningtyas ${ }^{1}$, I Made Bagus Dwiarta ${ }^{2}$, R. Bambang Dwi Waryanto ${ }^{3}$ \\ Bisma Arianto ${ }^{4}$ \\ ${ }^{124}$ Prodi Manajemen, Fakultas Ekonomi, Universitas PGRI Adi Buana Surabaya \\ ${ }^{3}$ Prodi Akuntansi, Fakultas Ekonomi, UNIPA Surabaya \\ E-mail : widhayani@unipasby.ac.id
}

\begin{abstract}
ABSTRAK
Potensi besar yang dimiliki Desa Kebontunggul Kecamatan Gondang Kabupaten Mojokerto meliputi peternakan unggas, perikanan lele, industri mebel, industri rumah tangga (keripik tortila, jamur dan jamu) dan wisata edukasi. Namun, permasalahan utama yang dihadapi oleh mitra adalah mengenai sumber daya pengelolaan BUMDes yang sangat kurang memadai, hal ini dibuktikan dengan minimnya sumber daya manusia yang bisa memanfaat teknologi informasi atau multimedia untuk membantu kegiatan promosi potensi desa. Melihat permasalahan utama yang dialami oleh BUMDes Kebontunggul, maka solusi yang ditawarkan antara lain dengan memberikan pelatihan Informasi Teknologi (IT) bagi pengelola BUMDes sehingga dapat membantu untuk meningkatkan promosi potensi Desa Kebontunggul khususnya potensi desa Wisata Edukasi Terpadu "Lembah Mbencirang". Dalam rangka Tri Dharma Perguruan Tinggi, tim dosen Universitas PGRI Adi Buana Surabaya tergerak untuk melakukan pengabdian kepada masyarakat. Tujuan dari program ini adalah agar Desa Kebontunggul dapat mengoptimalkan pembangunan perekonomian melalui Badan Usaha Milik Desa (BUMDes) guna meningkatkan promosi potensi di daerah tersebut. Selanjutnya dengan dibantu oleh mahasiswa, tim dosen menjelaskan bagaimana cara memaksimalkan fungsi dan peran BUMDes antara lain dengan cara menggunakan teknologi informasi bagi pengelola BUMDes sehingga dapat membantu untuk meningkatkan promosi potensi Desa Kebontunggul khususnya potensi desa Wisata Edukasi Terpadu "Lembah Mbencirang".
\end{abstract}

Kata kunci : Desa Kebontunggul, BUMDes, Promosi, Teknologi Informasi, Multimedia

\begin{abstract}
The great potential of Kebontunggul Village, Gondang district, Mojokerto Regency includes poultry farming, catfish fisheries, furniture industry, home industry (Tortilla chips, mushrooms and herbs) and educational tourism. However, the main issues faced by partners is that the BUMDes management resources are very inadequate. This is evidenced by the lack of human resources who able to utilize technology to support promote potential village activities. Recognizing these issues experienced by the Kebontunggul Village BUMDes, the community service team offered team offered several solutions include providing Information Technology (IT) training for BUMDes managers so that it can help to increase the promotion potential of Kebontunggul Village especially the potential of Integrated Education Tourism Village "Lembah Mbencirang". In the framework of the Tri Dharma of Higher Education, the lecturer team of PGRI Adi Buana University in Surabaya was moved to do community service. The purpose of this program is that Kebontunggul Village can optimize economic development through Village-Owned Enterprises (BUMDes) to increase the promotion of potential in the area. Furthermore, assisted by students, the lecturer team explained how to maximize the functions and roles of BUMDes, among others by using information technology for BUMDes
\end{abstract}


managers so that it could help to increase the potential promotion of Kebontunggul Village especially the potential of Integrated Education Tourism Village " Lembah Mbencirang ".

Keywords : Kebontunggul Village, BUMDes, Promotion, Information Technology, Multimedia

\section{PENDAHULUAN}

Kebontunggul merupakan suatu desa yang terletak pada Kecamatan Gondang Kabupaten Mojokerto yang memiliki usaha besar dalam bidang peternakan, perikanan, industri mebel, industri rumah tangga, dan wisata edukasi. Desa tersebut berupaya untuk dapat membangun perekonomian masyarakat yang lebih baik dengan cara meningkatkan hasil usaha melalui pemberdayaan BUMDes serta desa wisata yang menonjolkan kearifan lokal serta keindahan alam yang dimiliki oleh "Lembah Mbencirang". BUMDes diharapkan dapat membantu masyarakat untuk turut mempromosikan produk-produk lokal melalui bazar ataupun pameran produk sehingga produk tersebut dapat lebih dikenal oleh masyarakat yang berada tidak hanya di sekitar Mojokerto tapi juga seluruh wilayah Jawa Timur. Hal ini sesuai dengan dasar tujuan didirikannya Badan Usaha Milik Desa yakni untuk mendukung usaha untuk meningkatkan pendapatan masayarakat dan desa, sesuai dengan kebutuhan dan potensi yang dimiliki oleh desa (PP No.72, Psl.78, 2005). Akan tetapi, BUMDes Kebontunggul saat ini mengalami kendala yakni terkait dengan manajemen pengelolaan dimana BUMDes tidak memiliki Sumber Daya Manusia yang memiliki kemampuan memadai khususnya di bidang Teknologi Informasi atau pemanfaatan multimedia. Menurut Hofsetter (2001), multimedia dalam konteks komputer adalah pemanfaatan teknologi untuk membuat dan menggabungkan teks, grafik, audio, video, dengan menggunakan alat yang memungkinkan pengguna untuk berinteraksi, berkreasi, serta berkomunikasi. Penggunaan multimedia saat inipun telah berkembang pesat pada berbagai bidang kegiatan. Selain itu, berkembangnya sistem online, turut mendorong meningkatnya penggunaan multimedia untuk memenuhi beragam kebutuhan manusia baik, barang, jasa, maupun informasi. Saat ini multimedia berbasis online yang telah banyak digunakan antara lain Facebook, Instagram, Whatsupp, Youtube, dan sebagainya.

Kembali melihat permasalahan yang dialami oleh BUMDes Kebontunggul, maka solusi yang dapat ditawarkan antara lain adalah dengan memberikan pelatihan Informasi Teknologi (IT) bagi pengelola BUMDes. Pelatihan yang dimaksud adalah untuk memperbaiki penguasaan berbagai keterampilan dan teknik pelaksanaan pekerjaan tertentu, terperinci dan rutin (Handoko, 2001:104). Pelatihan adalah usaha untuk memperbaiki performasi pekerjaan pada suatu bidang pekerjaan tertentu supaya efektif.. Banyak manfaat yang bisa diperoleh dengan diadakannya kegiatan pelatihan. Menurut Simamora (2003:349), beberapa manfaat yang dapat diperoleh dari pelatihan yakni antara lain 1) Menciptakan sikap, loyalitas dan kerjasama yang lebih menguntungkan meningkatkan kuantitas dan kualitas produktifitas 2) Mengurangi waktu belajar yang diperlukan karyawan agar mencapai standar-standar kinerja yang dapat diterima 
3) Membantu dalam meningkatkan dan pengembangan pribadi karyawan 4) Memenuhi kebutuhan-kebutuhan perencanaan sumber daya manusia. Pelatihan juga harus mencakup pengalaman belajar, aktifitas-aktifitas yang terencana dandesain sebagai jawaban atas kebutuhan-kebutuhan yang berhasil diidentifikasikan.

Selain itu, penyuluhan tentang manfaat multimedia berbasis online juga akan diberikan kepada seluruh pengelola BUMDes serta masyarakat desa setempat. Dengan diberikannya pelatihan dan penyuluhan tersebut, pengelola BUMDes diharapkan dapat bekerja lebih optimal dan lebih efisien dengan adanya penggunaan teknologi informasi dalam berbagai kegiatan manajemen BUMDes yang dilakukan setiap hari. Selain itu, baik pengelola BUMDes maupun masyarakat dapat memiliki pengetahuan lebih mengenai pentingnya pemanfaatan multimedia dalam upaya meningkatkan usaha desa. Dengan diberikannya pelatihan dan penyuluhan, diharapkan pula pengelola BUMDes dan seluruh masyarakat dapat bekerjasama untuk mempromosikan beragam potensi Desa Kebontunggul khususnya potensi wisata alam melalui penggunaan berbagai media online seperti Instagram, Youtube, dan sebagainya.

\section{METODE PELAKSANAAN}

Metode Pelaksanaan yang berkaitan dengan (1) Pendidikan Masyarakat, misalnya dengan memberikan penyuluhan untuk meningkatkan pemahaman serta kesadaran, (2) Difusi Ipteks, misalnya melalui kegiatan yang menghasilkan produk bagi kelompok mitra, (3) Pelatihan, misalnya untuk menghasilkan keterampilan tertentu melalui kegiatan mendemonstrasikan atau mencontohankan, (4) Mediasi, misalnya kegiatan tim pengabdi Program Pengabdian Kepada Masyarakat ini fokus pada mengoptimalkan pengelolaan Badan Usaha Milik Desa (BUMDes) di Desa Kebontunggul dengan pemanfaatan multimedia sebagai media promosi berbagai potensi yang ada di desa tersebut. Harapan dari kegiatan ini adalah menuju desa yang mandiri dan kreatif dalam meningkatkan kesejahteraan masyarakat.

Agar dapat tercapai sasaran dan tujuan yang telah ditetapkan dalam program pengabdian kepada masyarakat di Desa Kebontunggul ini dilakukan penyuluhan dan pelatihan oleh Dosen Fakultas Ekonomi yang dibantu oleh mahasiswa dengan pendanaan diperoleh dari Lembaga Penelitian dan Pengabdian Masyarakat Universitas PGRI Adi Buana Surabaya. Tahapan yang dilakukan dalam program ini 1) survey lokasi untuk menentukan permasalahan dan potensi Desa Kebontunggul, 2) Koordinasi dengan tim pelaksana program, 3) Koordinasi dengan mahasiswa untuk membantu pelaksanaan program, 4) Pelaksanaan program pengabdian kepada masyarakat, 5) evaluasi hasil pengabdian kepada masyarakat. 


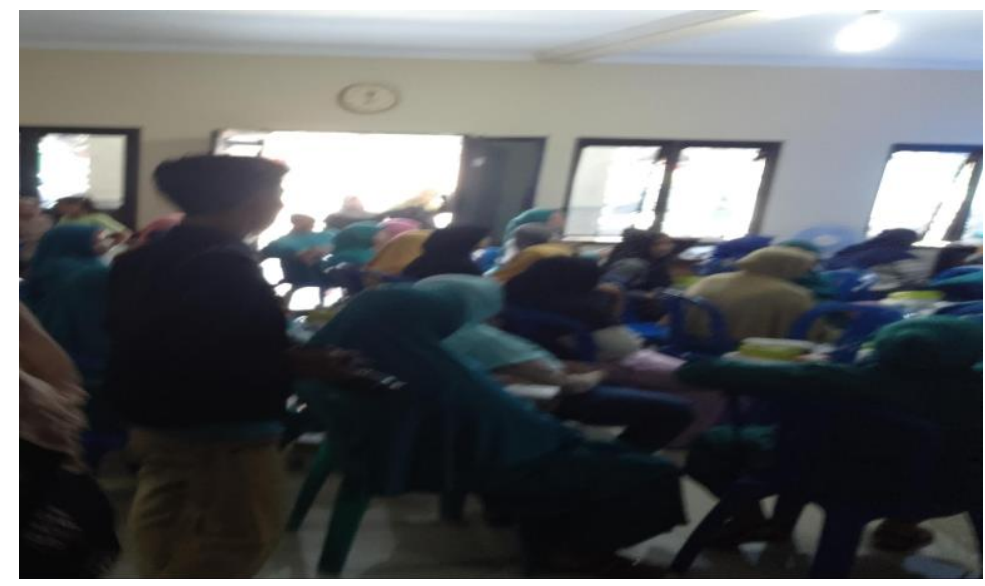

Gambar 1. Kegiatan penyuluhan dan pelatihan

\section{HASIL DAN PEMBAHASAN}

Permasalahan utama yang dihadapi oleh mitra adalah mengenai manajemen pengelolaan BUMDes. Saat ini pengelolaan BUMDes hanya dilakukan secara manual. Hal ini karena Sumber Daya Manusia pengelola BUMDes memiliki kemampuan yang sangat terbatas dalam memanfaatkan teknologi informasi dan multimedia untuk membantu kegiatan promosi potensi desa. Melihat permasalahan utama yang dialami oleh BUMDes Desa Kebontunggul, maka solusi yang ditawarkan antara lain dengan memberikan pelatihan Informasi Teknologi (IT) bagi pengelola BUMDes sehingga dapat membantu untuk meningkatkan promosi potensi Desa Kebontunggul khususnya potensi desa Wisata Edukasi Terpadu "Lembah Mbencirang". Pelatihan yang diberikan pada BUMdes Desa Kebontunggul Kecamatan Gondang Kabupaten Mojokerto antara lain adalah memberikan pelatihan pemanfaatan teknologi informasi serta berbagai multimedia khususnya berbasis online sebagai media promosi destinasi wisata dan produk oleh-oleh desa wisata di Desa Kebontunggul Kecamatan Gondang Kabupaten Mojokerto

Kemudian, Desa Kebontunggul ini memiliki visi mewujudkan masyarakat adil dan makmur serta pemerataan pembangunan di segala bidang dan misinya adalah meningkatkan peran serta masyarakat desa Kebontunggul dalam mengenali, menganalisis sekaligus mencari pemecahan terhadap masalah-masalah prioritas pembangunan desa Kebontunggul, terutama di bidang fisik prasarana, ekonomi dan sosial budaya. Dalam mewujudkan visi dan misi desa Kebontunggul tersebut, setiap desa memiliki suatu badan usaha yang berguna untk memenuhi kebutuhan masyarakat, terutama kebutuhan pokok dan tersedianya sumber daya desa yang belum dimanfaatkan, serta sumber daya manusia yang mampu mengelola badan usaha sebagai aset penggerak perekonomian masyarakat. Salah satu upaya yang dapat dilakukan adalah optimalisasi pembangunan Badan Usaha Milik Desa (BUMDes) guna menuju desa yang mandiri dan kreatif dalam meningkatkan kesejahteraan masyarakat di daerah. Dengan adanya penyuluhan informasi tentang optimalisasi BUMDes yang diberikan melalui kegiatan 
Pengabdian Masyarakat ini, kinerja BUMDes menjadi lebih baik dengan dilibatkannya masyarakat setempat secara optimal khususnya dalam bidang promosi melalui media elektronik, sehingga setiap desa dapat lebih meningkatkan hasil usahanya sesuai dengan potensi masing-masing yang ada di desa tersebut.

\section{DAMPAK DAN MANFAAT KEGIATAN}

Setelah dilakukan pelatihan dan penyuluhan, pengelola BUMDes dapat lebih optimal menggunakan sarana media eletronik dengan sistem online dalam segala kegiatan khususnya kegiatan promosi. Kemudian para pengelola BUMDes juga mendapatkan informasi mengenai pentingnya kerjasama dengan masyarakat setempat untuk memajukan potensi usaha yang ada di desa tersebut. Menyadari hal tersebut, pengelola BUMDes telah merencanakan program pelatihan teknologi informasi khususnya multimedia berbasis online bagi masyarakat setempat. Selain itu, para perangkat desa juga memberikan motivasi bagi masyarakat untuk ikut berpartisipasi dalam pengelolaan BUMDes. Manfaat yang diperoleh selain perekonomian dan kesejahteraan masyarakat setempat meningkat, tercipta sinergi dan semangat kerja gotong royong yang lebih baik antara masyarakat dengan para pengelola BUMDes sehingga loyalitas untuk memajukan desa tidak hanya datang dari perangkat desa namun juga dari seluruh masyarakat Desa Kebontunggul.

\section{SIMPULAN}

Di era digital seperti saat ini, pemanfaatan media elektronik dan sistem online sangatlah penting dalam segala kegiatan yang ada pada BUMDes baik kegiatan manajemen maupun pemasaran. Pemanfaatan teknologi informasi ini dengan tujuan agar dapat mengoptimalkan hasil usaha sesuai dengan tujuan yang diharapkan yakni masyarakat yang makmur dan sejahtera. Namun, pemanfaatan teknologi ini tentu saja membutuhkan Sumber Daya yang memadai baik dari segi manusia maupun segala perangkat elektroniknya. Pelatihan dan penyuluhan sangat dibutuhkan untuk dapat meningkatkan skill serta kesadaran Sumber Daya Manusia akan pentingnya pemanfaatan teknologi informasi tersebut dalam rangka memajukan segala bentuk kegiatan usaha. Selain itu kerjasama yang baik antara pengelola BUMDes dengan masyarakat setempat juga dibutuhkan agar tujuan yang diharapkan dapat tercapai dengan cepat dan optimal.

\section{UCAPAN TERIMA KASIH}

Ucapan terima kasih kami sampaikan kepada tim Dosen Fakultas Ekonomi, mahasiswa yang secara langsung turun dalam pelaksanaan kegiatan PPM di desa tersebut, pihak LPPM Universitas PGRI Adi buana Surabaya selaku pemberi dana sehingga kami dapat melakukan kegiatan Program Pengabdian Masyarakat (PPM), serta segenap masyarakat dan perangkat BUMDes yang telah ikut berpartisipasi baik dalam kegiatan pelatihan maupun penyuluhan. Kegiatan ini pastilah kurang sempurna, oleh 
karena itu dibutuhkan saran maupun masukan dari pihak-pihak lain agar semakin baik kedepannya.

\section{DAFTAR PUSTAKA}

Undang Undang Badan Usaha Milik Desa (BUMDes), PP No. 72 (2005). Psl.78 (ayat 1).

Hofsetter, Fred T. (2001). Multimedia Literacy. Third Edition. McGraw-Hill International Edition : New York.

Handoko, T. Hani. (2001). Manajemen Personalia dan Sumber Daya Manusia. Yogyakarta: BPFE Yogyakarta.

Simamora, H. (2003). Manajemen Sumber Daya Manusia. Yogyakarta. 